\title{
Silver-Spotted Skipper; Epargyreus clarus (Cramer) (Insecta: Lepidoptera: Hesperidae: Pyrginae) ${ }^{1}$
}

Donald W. Hall ${ }^{2}$

\section{Introduction}

The silver-spotted skipper, Epargyreus clarus (Cramer), characterized by a large white spot on the underside of each hind wing, is one of our largest, most widespread and most recognizable skippers.

\section{Distribution}

The silver-spotted skipper is found throughout most of the United States and into southern Canada (Scott 1986). In the West, it is more restricted to mountainous areas (Brock and Kaufman 2002).

\section{Description}

Adult: The wing spread is 1.75 to 2.40 inches (Daniels 2003). The upper-side of the wings is brown with a median row of yellowish-gold spots on the forewing that is also visible from beneath. The wing fringe is dashed with white. The under-side of the wings is brown with a large median irregular-shaped white patch on each wing and a short rounded tail. The Butterflies of America web site (Warren et al. 2007) has excellent photographs of pinned male and female adults.

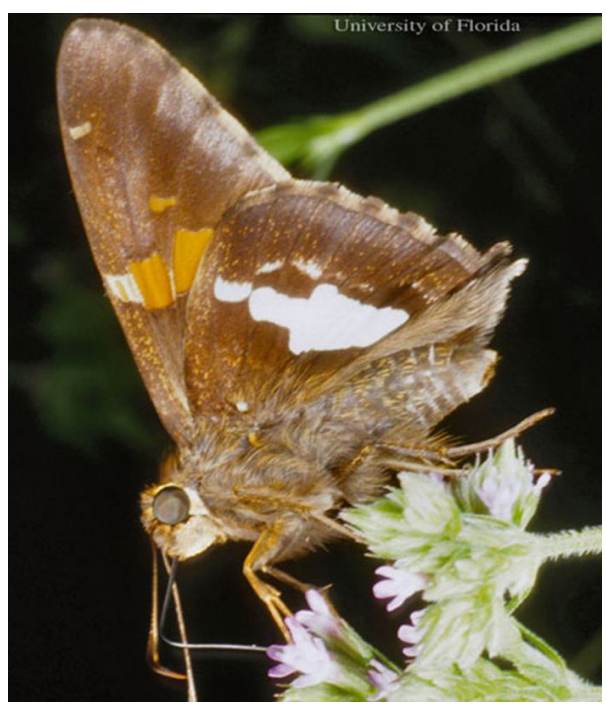

Figure 1. An adult silver-spotted skipper, Epargyreus clarus (Cramer), feeding at a flower. Credits: Photograph by: J.F. Butler, University of Florida

Egg: The eggs are green with a red top.

Larva: The larva is up to 2.0 inches in length. The head is dark reddish brown with large yellow eye patches. The prothoracic shield is brown. The abdomen is yellow with darker transverse stripes and spots. Prolegs are bright orange.

1. This document is EENY-439 (IN774), one of a series of Featured Creatures from the Entomology and Nematology Department, Florida Cooperative Extension Service, Institute of Food and Agricultural Sciences, University of Florida. Published: July 2008. This document is also available on Featured Creatures Website at http://creatures.ifas.ufl.edu. Please visit the EDIS Website at http://edis.ifas.ufl.edu.

2. Donald W. Hall, professor, Entomology and Nematology Department, Institute of Food and Agricultural Sciences, University of Florida, Gainesville, 32611.

The Institute of Food and Agricultural Sciences (IFAS) is an Equal Opportunity Institution authorized to provide research, educational information and other services only to individuals and institutions that function with non-discrimination with respect to race, creed, color, religion, age, disability, sex, sexual orientation, marital status, national origin, political opinions or affiliations. U.S. Department of Agriculture, Cooperative Extension Service, University of Florida, IFAS, Florida A. \& M. University Cooperative Extension Program, and Boards of County Commissioners Cooperating. Larry Arrington, Dean 


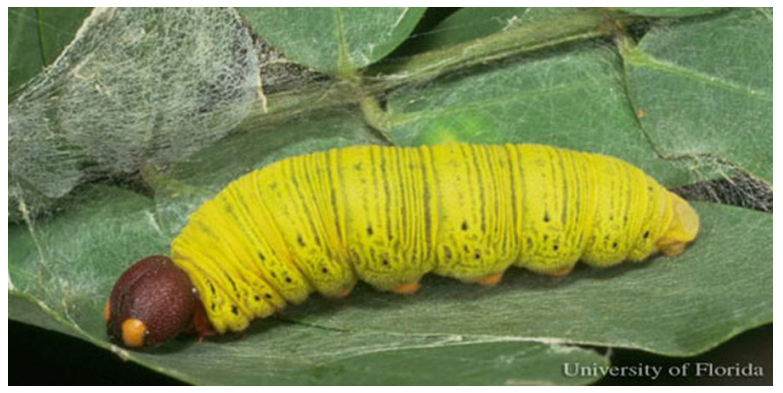

Figure 2. Larva of the silver-spotted skipper, Epargyreus clarus (Cramer), in opened leaf-shelter on false indigo. Credits: Photograph by: J.F. Butler, University of Florida

Pupa: The pupa is dark brown with black and white markings.

\section{Life Cycle and Biology}

Adults have the jerky flight typical of many skippers. They frequent edges of forests, swamps, brushy areas, and other open areas where nectar plants are found. Adults have long "tongues" and feed on nectar from a variety of flowers (Ifter et al. 1992, Tooker et al. 2002.), mud (Scott 1986, Brewer and Winter 1986), and occasionally on animal feces.

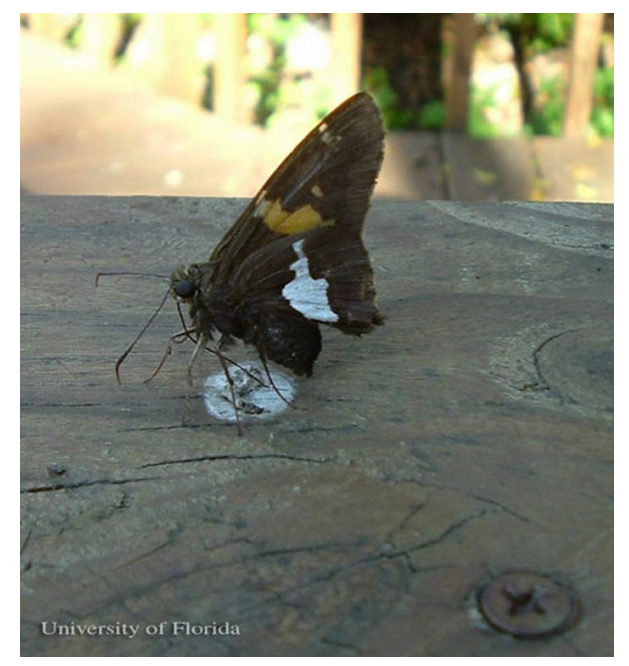

Figure 3. An adult silver-spotted skipper, Epargyreus clarus (Cramer), feeding at bird dropping. Credits: Photograph by: D.W. Hall, University of Florida

Adult males rest on tree limbs or other tall vegetation and fly out to investigate flying objects including females. Adult females are reported to lay their eggs directly on the host plants or occasionally on nearby non-host plants (Cech and Tudor 2005, Daniels 2003, Minno and Minno 1999, Opler and Krizek 1984).
Like most skippers, silver-spotted skipper larvae live in leaf shelters. First instar larvae make shelters on the apical halves of leaves by cutting a flap on the leaf margin, folding it over and attaching it with silk. Larger larvae often silk several leaves together to form shelters. During development, the larvae make four distinct types of shelters (Lind et al. 2001, Weiss et al. 2003). They leave the shelters only to feed or to make larger shelters. Presumably a major function of the shelters is protection from predators. However, Polistes (Vespidae) wasps learn to recognize the shelters to find the larvae and then extract them from the leaf nests (Jones et al. 2002, Weiss et al. 2004). The sphecid wasp, Stictia carolina (Fabricius), also sometimes provisions its nests with silver-spotted skipper larvae (Hook 1981).

When disturbed, larvae regurgitate a greenish, bitter-tasting, defensive chemical (Minno et al. 2005).

Insect frass may provide chemical cues for parasitic wasps to the location of prey insects (Weiss 2006). Many caterpillars that live in leaf nests, including the silver-spotted skipper, forcibly eject their frass for considerable distances to eliminate these chemical cues. Silver-spotted skipper larvae utilize their anal comb to throw their frass a distance up to 38 body lengths (Weiss 2003).

In addition to predation and parasitism by insects, the larvae are susceptible to a Baculovirus (nuclear polyhedrosis virus) infection (Nordin 1975).

When mature, the larvae pupate inside the leaf nest. The pupal stage is the overwintering stage (Allen 1997, Minno et al. 2005). There are three or more over-lapping generations in Florida - fewer in more northern parts of the distribution (Glassberg et al. 2000, Minno et al. 2005, Wagner 2005).

\section{Hosts}

The larvae feed on leaves of herbs, vines, shrubs, and trees in the pea family (Fabaceae) including false indigobush (Amorpha fruticosa L.), American hogpeanut (Amphicarpaea bracteata [L.] Fernald), Atlantic pidgeonwings or butterfly pea (Clitoria mariana L.), groundnut (Apios americana Medik.), American wisteria (Wisteria frutescens [L.] Poir.) and 
the introduced Dixie ticktrefoil (Desmodium tortuosum [Sw.] DC.), kudzu (Pueraria montana [Lour.] Merr.), black locust (Robinia pseudoacacia L.), Chinese wisteria (Wisteria sinensis [Sims] DC.) and a variety of other legumes (Minno et al 2005, Scott 1986). Females will oviposit on least snoutbean (Rynchosia minima [L.] DC.) and coralbean (Erythrina herbacea L.) but the larvae will not feed on these species (Scott 1986).

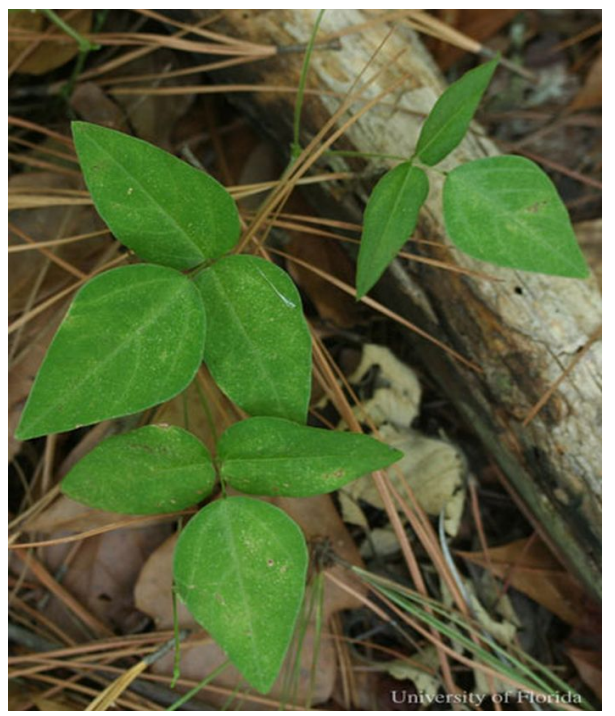

Figure 4. American hogpeanut, Amphicarpaea bracteata [L.] Fernald, a host plant for the silver-spotted skipper, Epargyreus clarus (Cramer). Credits: Photograph by: D.W. Hall, University of Florida

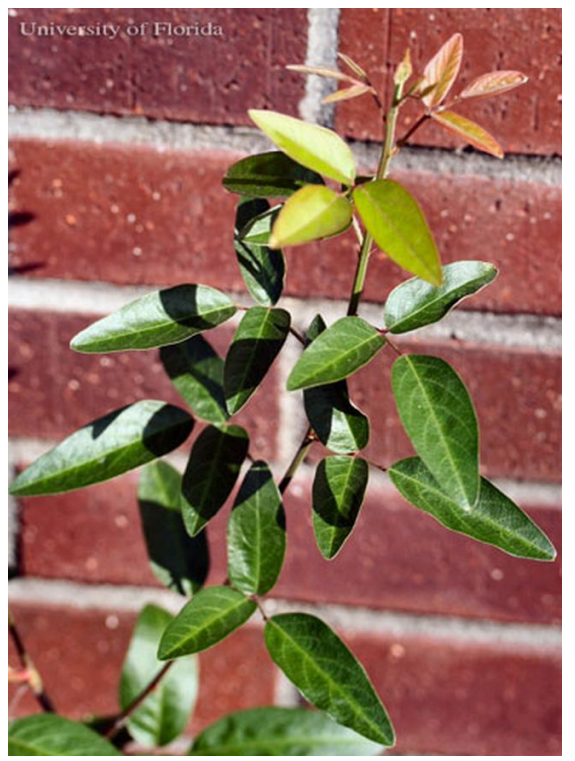

Figure 5. Dixie ticktrefoil, Desmodium tortuosum [Sw.] DC., a host plant for the silver-spotted skipper, Epargyreus clarus (Cramer). Credits: Photograph by: D.W. Hall, University of Florida

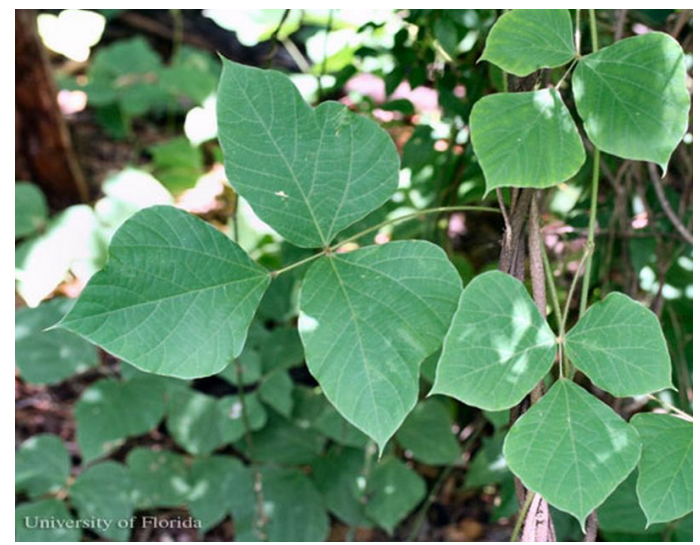

Figure 6. Kudzu, Pueraria montana [Lour.] Merr., a host plant for the silver-spotted skipper, Epargyreus clarus (Cramer). Credits: Photograph by: D.W. Hall, University of Florida

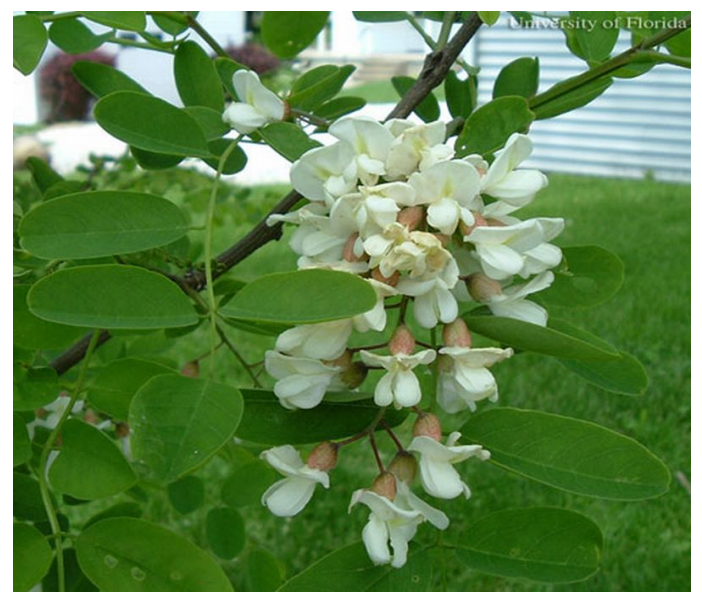

Figure 7. Black locust, Robinia pseudoacacia L., a host plant for the silver-spotted skipper, Epargyreus clarus (Cramer). Credits: Photograph by: D.W. Hall, University of Florida

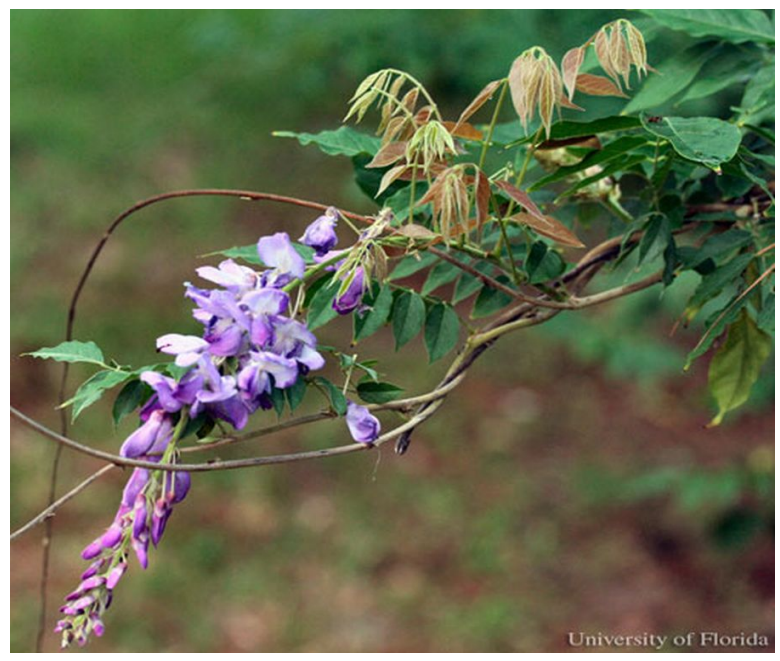

Figure 8. Chinese wisteria, Wisteria sinensis [Sims] DC., a host plant for the silver-spotted skipper, Epargyreus clarus (Cramer). Credits: Photograph by: D.W. Hall, University of Florida 


\section{Economic Importance}

Although it is reported to feed on soybean (Glycine max [L.] Merr.) (Minno and Minno 1999) and kidney bean (Phaseolus vulgaris L.) (Scott 1986), the silver-spotted skipper is never sufficiently common to be of economic importance and control measures are not required.

\section{Selected References}

- Allen TJ. 1997. The Butterflies of West Virginia and their Caterpillars. University of Pittsburgh Press. Pittsburgh, Pennsylvania. 400 pp.

- Brewer J, Winter D. 1986. Butterflies and Moths. Prentiss Hall, Inc. New York, New York. 194 pp.

- Brock JP, Kaufman K. 2002. Butterflies of North America. Houghton Mifflin Company. New York, New York. 383 pp.

- Cech R, Tudor G. 2005. Butterflies of the East Coast: An Observer's Guide. Princeton University Press. Princeton, New Jersey. 345 pp.

- Daniels JC. 2000. Butterflies 1: Butterflies of the Southeast. UF/IFAS. Card Set. SP 273.

- Daniels JC. 2003. Butterflies of Florida: Field Guide. Adventure Publications, Inc. Cambridge, Minnesota. 256 pp.

- Glassberg J, Minno C, Calhoun JV. 2000. Butterflies through Binoculars: Florida. Oxford University Press. New York, New York. 256 pp.

- Hook A. 1981. Hesperiidae as prey of Stictia carolina. Journal of the New York Entomological Society 89: 202-203.

- Ifter DC, Shuey JA, Calhoun JV. 1992. Butterflies and Skippers of Ohio. Ohio Biological Survey Bulletin New Series. Volume 9, No. 1. 212 pp.

- Jones MT, Castellanos I, and Weiss MR. 2002. Do leaf shelters always protect caterpillars from invertebrate predators? Ecological Entomology 27: 753-757.
- Lind EM, Jones MT, Long JD, Weiss MR. 2001. Ontogenetic changes in leaf-shelter construction by larvae of Epargyreus clarus (Hesperiidae), the silver-spotted skipper. Journal of the Lepidopterists' Society 54: 77-82.

- Minno MC, Butler JF, Hall DW. 2005. Florida Butterfly Caterpillars and their Host Plants. University Press of Florida. Gainesville, Florida. $341 \mathrm{pp}$.

- Minno MC and Minno M. 1999. Florida Butterfly Gardening: A Complete Guide to Attracting, Identifying, and Enjoying Butterflies of the Lower South. University Press of Florida. Gainesville, Florida. 210 pp.

- Nordin GL. 1975. A nuclear polyhedrosis virus from the silver-spotted skipper Epargyreus clarus (Lepidoptera: Hesperiidae). Journal of Invertebrate Pathology 26: 130-134.

- Opler PA, Krizek GO. 1984. Butterflies East of the Great Plains. The Johns Hopkins University Press. Baltimore, Maryland. 294 pp.

- Scott JA. 1986. The Butterflies of North America: A Natural History and Field Guide. Stanford University Press. Stanford, California. $583 \mathrm{pp}$.

- Tooker JF, Reagel Pf, Hanks LM. 2002. Nectar sources of day-flying Lepidoptera of central Ilinois. Annals of the Entomological Society of America. 95(1): 84-96.

- Wagner DL. 2005. Caterpillars of Eastern North America. Princeton University Press. Princeton, New Jersey. 512 pp.

- Warren WD, Davis K, Pelham JP, Stangeland M. (2007). Butterflies of America. http://butterfliesofamerica.com/ epargyreus_c_clarus.htm (25 June 2008).

-Weiss MR. 2003. Good housekeeping: why do shelter-dwelling caterpillars fling their frass? Ecology Letters 6: 361-370.

-Weiss MR. 2006. Defecation behavior and ecology of insects. Annual Review of Entomology 51: 635-661. 
- Weiss MR, Lind EM, Jones MT, and Long JD, Maupin JL. 2003. Uniformity of leaf shelter construction by larvae of Epargyreus clarus (Hesperiidae), the silver-spotted skipper. Journal of Insect Behavior 16: 465-480.

- Weiss MR, Wilson EE, Castellanos I. 2004. Predatory wasps learn to overcome the shelter defenses of their larval prey. Animal Behaviour 68: 45-54. 